\title{
Induction of Phage Formation in Lysogenic Escherichia coli by Myxin
}

\author{
By S. M. LESLEY AND R. M. BEHKI \\ Chemistry and Biology Research Institute, Research Branch, \\ Canada Department of Agriculture, Ottawa, Canada
}

(Accepted for publication I I January I972)

The primary effect of the antibiotic myxin (I-hydroxy-6-methoxyphenazine-5, Io dioxide; Peterson, Gillespie \& Cook, I966) is the inhibition of DNA biosynthesis (Lesley \& Behki, 1967) but synthesis of new DNA has been shown to occur in myxin-exposed cells following infection with $\mathrm{T}_{4}$ bacteriophage (Behki \& Lesley, 197I). At a myxin concentration of $5 \mu \mathrm{g} / \mathrm{ml}$, Escherichia coli are rapidly killed (50\% survivors at $5 \mathrm{~min}$ ), DNA synthesis is inhibited by $7 \mathrm{~min}$, and intracellular DNA is extensively degraded (Lesley \& Behki, I967; Lesley \& Behki, I97I). Agents that act as inducers of phage production in lysogenic bacteria appear to have in common the above three properties and the effect of myxin on the induction and development of active phage from the prophage state in lysogenic bacterium $E$. coli $\mathrm{KI} 2(\lambda) \mathrm{Y} I 0$ was therefore examined.

Escherichia coli $\mathrm{KI} 2(\lambda)$ Y IO cultures in nutrient broth were used in the logarithmic phase of growth at $2 \times 10^{8}$ cells $/ \mathrm{ml}$. Samples incubated with $0,0.1,0.5, \mathrm{I} \cdot 0$ and $2 \cdot 0 \mu \mathrm{g} / \mathrm{ml}$ myxin were aerated with vigorous shaking at $37^{\circ} \mathrm{C}$. The growth and lysis of the cultures were followed turbidometrically. All the cultures showed a logarithmic increase in extinction for about $60 \mathrm{~min}$. Thereafter the turbidity of cultures exposed to $0.5, \mathrm{I} \cdot 0$ and $2.0 \mu \mathrm{g}$ myxin $/ \mathrm{ml}$ rapidly decreased due to lysis of the cells and release of $\lambda$ phage. After a further $60 \mathrm{~min}$ the extinction of these cultures decreased by 28,62 and $68 \%$ respectively for the three myxin concentrations and after another $\mathrm{I} h$ they were almost clear. This characteristic growth pattern in the presence of myxin resembles very closely the reported growth curves after induction of lysogenic bacteria with appropriate doses of either ultraviolet light (Weigle \& Delbrück, I95I), inducing chemical agents (Borek \& Rockenbach, 1954; Gots, Bird \& Mudd, I955) or mitomycin C (Otsuji, Sekiguchi, Lijima \& Takagi, 1959). Two non-lysogenic strains of $E$. coli tested did not exhibit this phenomenon with any concentration of myxin (up to $10 \mu \mathrm{g} / \mathrm{ml}$.)

The effect of myxin on the intracellular multiplication of $\lambda$ phage was, therefore, examined in Escherichia coli $\mathrm{KI} 2(\lambda)$ Y 10 . Cultures were exposed to different myxin concentrations and the number of viable cells and infective centres were titrated after $30 \mathrm{~min}$. In the culture exposed to $0.5 \mu \mathrm{g}$ myxin $/ \mathrm{ml}$ the number of infective centres reached a maximum of about $25 \%$ of the original number of colony-formers present (Fig. I). Under these conditions $40 \%$ of the original cells retained their colony-forming ability. At $2 \mu \mathrm{g}$ myxin $/ \mathrm{ml}$, when almost all the treated bacteria were killed, $37 \%$ of the original number were titratable as infective centres. The induction of lambda phage was not severely inhibited with up to Io $\mu \mathrm{g}$ myxin $/ \mathrm{ml}$. After full lysis of the cells the maximum yield of phage was found, with $2 \mu \mathrm{g}$ myxin $/ \mathrm{ml}$, to be $6.6 \times 10^{9} / \mathrm{ml}$ when titrated on the indicator strain $\mathrm{K}_{1} \mathrm{~T}_{4}$.

Myxin can, therefore, be added to the list of agents that induce the production of bacteriophage in lysogenic bacteria. It is similar in its antimicrobial activity to mitomycin C (Reich, Shatkin \& Tatum, 196I), streptonigrin (White \& White, 1968) and nalidixic acid (Goss, 


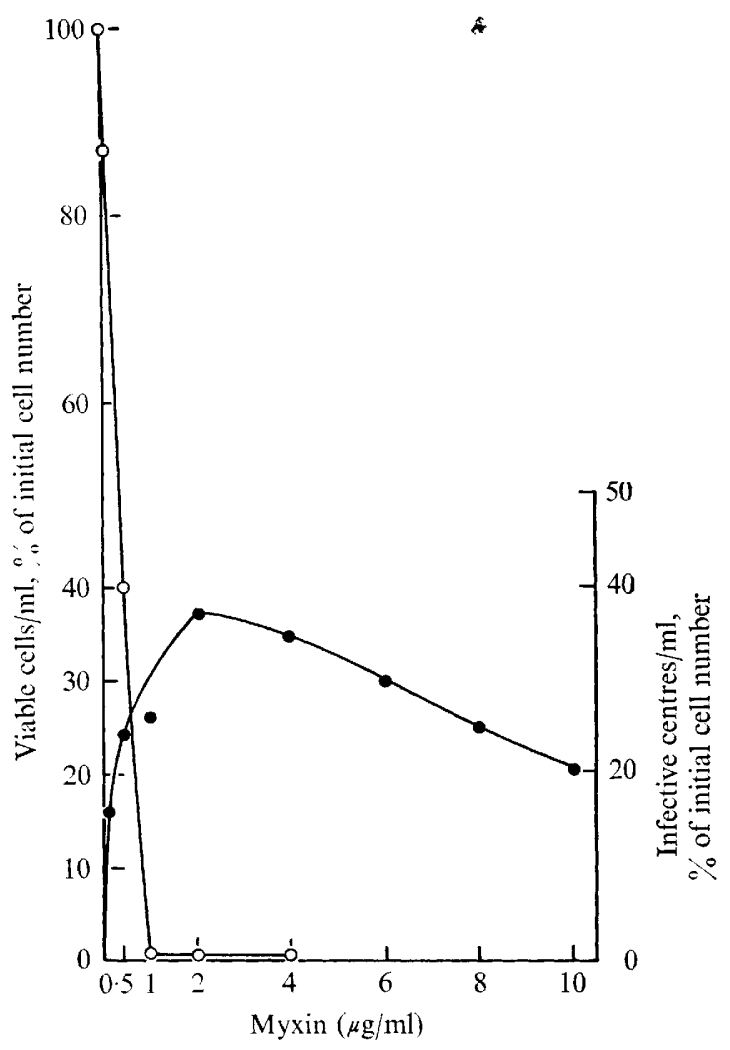

Fig. I. Percent viable cells and infective centres with Escherichia coli KI2 ( $\lambda$ )Y 10 as a function of myxin concentrations. The data has been normalized by expressing the number of viable cells and infective centres as a percentage of initial number of colony-formers. $\mathrm{O}-\mathrm{O}$, Viable cells; - infective centres.

Dietz \& Cook, 1965) in that DNA synthesis is inhibited, intracellular DNA is degraded and cell death rather than bacteriostasis results. Structurally, these compounds differ significantly in that mitomycin $\mathrm{C}$ and streptonigrin are quinones, myxin is a phenazine derivative and nalidixic acid is a napthyridine derivative (Lesher et al. 1962). Infectious $T_{4}$ particles are produced in the presence of myxin (Behki \& Lesley, 197I) but not in the presence of mitomycin $\mathrm{C}$. This indicates abnormal or biologically inactive bacteriophage DNA synthesis with the latter compound (Sekiguchi \& Takagi, 1960). Myxin may be useful in studies of differential synthesis of DNA species in such systems.

This paper is Contribution no. 718 .

\section{REFERENCES}

BehKI, R. M. \& Lesley, S. M. (I97I). Effect of myxin on deoxyribonucleic acid synthesis in Escherichia coli infected with $\mathrm{T}_{4}$ bacteriophage. Journal of Virology $7,372-378$.

BOREK, E. \& ROCKENBACH, J. (1954). Induction of phage formation in a lysogenic organism by irradiated leucovorin. Biochimica et biophysica acta 15, I40-141.

Goss, W. A., DieTz, W. H. \& CooK, T. M. (1965). Mechanism of action of nalidixic acid on Escherichia coli. II. Inhibition of deoxyribonucleic acid synthesis. Journal of Bacteriology 89, I068-1074. 
GoTs, J. S., BIRD, T. J. \& MUDD, S. (1955). L-Azaserine as an inducing agent for the development of phage in the lysogenic Escherichia coli. Biochimica et biophysica acta 17, 449-450.

Lesher, G. Y., Froelich, E. J., Gruett, M. D., Bailey, J. H. \& Brundage, R. P. (1962). I, 8-Napthyridine derivatives; a new class of chemotherapeutic agents. Journal of Medicinal and Pharmaceutical Chemistry 5, 1063-1065.

LESLEY, S. M. \& BeHKI, R. M. (1967). Mode of action of myxin on Escherichia coli. Journal of Bacteriology 94, $1837-1845$.

LesLey, S. M. \& BeHKI, R. M. (197I). Recovery of metabolic activity in Escherichia coli following limited exposure to myxin. Canadian Journal of Microbiology 17, I327-1333.

Peterson, E. A., Gillespie, D. C. \& CooK, F. D. (1966). A wide-spectrum antibiotic produced by a species of Sorangium. Canadian Journal of Microbiology 12, $221-230$.

Otsuis, N., Sekiguchi, M., Lijima, T. \& Takagi, Y. (1959). Induction of phage formation in lysogenic Escherichia coli $\mathrm{KI} 2$ by mitomycin C. Nature, London 184, 1079-1080.

Reich, F., Shatkin, A. J. \& TAtum, E. L. (196I). Bacteriocidal action of mitomycin C. Biochimica et biophysica acta 53, I32-r49.

SeKIGUCHI, M. \& TAKAGI, Y. (1960). Effect of mitomycin C on the synthesis of bacterial and viral deoxyribonucleic acid. Biochimica et biophysica acta 4r, 434-443.

Weigle, J. J. \& Delbrück, M. (195I). Mutual exclusion between an infecting phage and a carried phage. Journal of Bacteriology 62, 30I-3I3.

WhITE, H. L. \& WhITE, J. R. (I968). Lethal action and metabolic effects of streptonigrin on Escherichia coli. Molecular Pharmacology 4, 549-565. 